\title{
Hormonal Regulation of Ovarian Cellular Proliferation
}

\author{
Mrinalinl C. Rao," A. Rees Midgley, Jr. and \\ JoAnne S. Richards \\ Reproductive Endocrinology Program \\ Department of Pathology \\ University of Michigan \\ Ann Arbor, Michigan 48109
}

\section{Summary}

The steroid hormone estradiol, and the glycoprotein hormones follicle-stimulating hormone (FSH) and luteinlzing hormone (LH), are known to be essentlal for the growth and differentiation of follicles in the ovary. The present study was conducted to determine quantitatively the effects of estradiol, FSH and LH on proliferation of different ovarian cell types (granulosa and theca cells). The immature female hypophysectomized rat sequentlally primed with estradlol, FSH and LH was used as the experimental model. Prollferation was assessed by examining changes in total DNA, incorporation of ${ }^{3} \mathrm{H}$-thymidine Into DNA and labeling index in specific cell types. Estradiol and FSH each acted on follicles at different stages of development to stimulate prollferative activity of both granulosa and theca cells. Continued administration of either hormone caused a decrease in the proliferative activity of both cell types. These observations have been interpreted to indicate that estradiol and FSH can each alter the length of the specific phases of the cell cycle. A luteinizing dose of LH caused a cessation of proliferation in luteinizing granulosa cells while stimulating a limited prollferation of theca cells. Absence of the appropriate hormonal stimulus caused both granulosa and theca cells to stop proliferating and the follicles to undergo atresia. These results indicate that, depending upon the state of differentiation of granulosa and theca cells, estradiol, FSH and LH can stimulate or inhibit the ability of these cells to proliferate.

\section{Introduction}

The growth and differentiation of ovarian follicles in the rat appear to be dependent upon appropriate stimulation by both estrogens and gonadotropins (Richards and Midgley, 1976). While the effects of estradiol and gonadotropins on granulosa cell receptor content for these hormones have been carefully related to morphological growth stages of ovarian follicles, a similar correlation between stages of follicular differentiation and the effects of

* Present address: Gastroenterology Section, Department of Medicine, University of Chicago, Post Box 400, 950 East 59th Street. Chicago, Illinois 60637 . these hormones on proliferation in different ovarian cell types has not been made. Estrogens have been shown to increase granulosa cell proliferation and ovarian responsiveness to follicle-stimulating hormone (FSH) in immature hypophysectomized rats (Pencharz 1940; Williams, 1940; Bradbury, 1961; Goldenberg, Vaitukaitis and Ross, 1972). Sequential treatment of these estrogen-primed rats with FSH stimulates further granulosa cell proliferation (Ryle, 1969) with the formation of large antral follicles. The latter undergo luteinization upon exposure to an ovulatory dose of luteinizing hormone (LH) (Richards and Midgley, 1976). The effects of $\mathrm{LH}$ on cellular proliferation in association with the induction of luteinization have been less extensively studied (Pedersen and Peters, 1971; Bartosik, Szarowski and Stone, 1974). Although studies in the intact neonatal rat (Goldenberg, Reiter and Ross, 1973) suggest that at least one gonadotropin (pregnant mare serum gonadotropin) stimulates theca cell development prior to granulosa cell proliferation, little evidence exists for the effects, if any, of estrogens, FSH or LH on the proliferative activity of ovarian cell types other than granulosa cells (Hori et al., 1970; Eshkol and Lunenfeld, 1972).

The present investigation has been conducted to study the effects of estradiol, $\mathrm{FSH}$ and $\mathrm{LH}$ on correlations between hormone administration and subsequent follicular development and proliferation, in a well characterized differentiating system - the immature hypophysectomized female rat sequentially primed with estradiol, FSH and LH.

\section{Results}

\section{Efficlency of Granulosa Cell Expression}

During granulosa cell isolation, not all of the granulosa cells are expressed, and a small number of nonexpressed granulosa cells remain with the theca interstitial tissue. To determine the extent to which nonexpressed granulosa cells contaminate this residual tissue, the efficiency of granulosa cell expression was estimated. Based on the knowledge that receptors for $\mathrm{FSH}$ are restricted to granulosa cells (Midgley, 1974), the distribution of FSH receptors in the expressed granulosa cells and residual tissue was determined as a percentage of total ovarian FSH receptor content. The efficiency of expression ranged from 76 to $92 \%$ at different stages of the treatment regimen, but the differences were not statistically significant $(p>0.1)$ as measured by Student's $t$ test.

Effects of Estradiol on Ovarian Cell Proliferation To determine the effects of estradiol on the prolif- 
erative activity of ovarian cell types, the labeling index (proportion of labeled cells), the incorporation ratio (amount of $0.3 \mathrm{M}$ acid-insoluble label incorporated into DNA $\div$ concentration of $0.3 \mathrm{M}$ acid-soluble label in the ovary) and the total amount of DNA present were measured independently in the granulosa and residual (theca interstitial) tissue. As seen in Figure 1, both the labeling index and the incorporation ratio of granulosa cells showed maximal increases $(4.5$ and 4.4 fold, respectively) after 2 days of estradiol treatment, and declined to near control values after 4 days of treatment. In all treatment groups, control tissues (intestinal epithelium; data not shown) uniformly exhibited heavily labeled cells. In contrast, the granulosa cells of the ovary from different treatment groups showed a variation in the intensity of labeling. As seen in Figures $2 \mathrm{C}$ and $2 \mathrm{D}$, granulosa cells after 2 and 3 days of estradiol treatment were heavily labeled (>14 grains per nucleus), whereas all the labeled cells in untreated animals (Figure $2 A)$ and in animals treated with estradiol for 4 days (Figure 2E) were lightly labeled (7-14 grains per nucleus). Animals treated with estradiol for 1 day showed both lightly and heavily labeled cells (Figure 2B).

Concomitant with its stimulation of granulosa cell proliferation, estradiol increased the proliferative activity of the cells in the theca interstitial tissue. Thus treatment with estradiol for 3 days caused a dramatic 30 fold (maximal) increase in the labeling index which declined to a value 4 fold that of control by the fourth day of treatment (Figure 1A). As seen in Figure 1B, the incorporation ratios in the residual tissues showed a similar pattern, but of a lesser magnitude, with a maximal increase (6.4 fold) after only 2 days of estradiol treatment which declined to a value 2.5 fold that of control by the fourth day of treatment. In those treatment groups in which the theca layers could be clearly distinguished, a large number $(90 \%)$ of the labeled cells in the theca interstitial tissue were in the theca layers. As shown in Figure 3, estradiol did not substantially alter the amount of label present per $\mu \mathrm{g}$ DNA in the $0.3 \mathrm{M}$ acid-soluble fraction in either granulosa cells or residual tissue.

The increase in proliferation was also reflected by an increase in the amount of DNA ( $\mu \mathrm{g}$ per ovary) present in the granulosa and residual tissues (Figure 4). In response to estradiol, the greatest amount of DNA in both tissues was seen following treatment with estradiol for 3 days. A fourth day of treatment caused no significant change. Figure 4 also reveals that over the 4 day treatment period, vehicle-treated controls showed no measurable change in DNA content. Although not shown, the well known increase in follicular size and ovarian weight in response to estradiol was also observed.

\section{Effects of hFSH on Ovarian Cell Proliferation}

Since estrogen is known to increase the responsiveness of the ovary to gonadotropins (Goldenberg et al., 1972), hFSH ( $2 \mu \mathrm{g}$ per day) was administered to rats primed with estradiol (4 days) to determine the effects of FSH on proliferation. Treatment with $\mathrm{FSH}$ for 1 day stimulated the proliferative activity of granulosa cells as seen by an increase in the labeling index ( 6 fold) and in the incorporation ratio (1.6 fold) depicted in Figures $1 \mathrm{~A}$ and $1 \mathrm{~B}$, respectively. An additional day of treatment caused only a slight decrease in the proliferative activity. Withdrawal of FSH treatment caused a rapid decrease in DNA synthesis in granulosa cells (data not shown) and rapidly led to atresia as reported by Richards et al. (1976). The cells of the nongranulosa component also responded to FSH with increased proliferative activity. The labeling index of the theca interstitial tissue increased 1.6 fold after the first day of treatment, and increased an additional $\mathbf{1 . 5}$ fold after the second day of $\mathrm{FSH}$ administration (Figure 1A). The majority of the labeled cells $(80 \%)$ in the theca interstitial tissue were identified in the theca layers. Thymidine incorporation measured in the residual tissue showed no significant increase after the first day of treatment, but a $\mathbf{1 . 7}$ fold increase was observed after 2 days of FSH treatment (Figure 1B). Like estradiol, FSH did not alter the concentration of label in the $0.3 \mathrm{M}$ acid-soluble fraction of granulosa cells. As shown in Figure 3, however, treatment with FSH for 2 days caused a 2 fold increase of label in the acid-soluble fraction of the residual tissue. The stimulation of proliferation by FSH was also evident in an increase in the total amount of DNA present in the granulosa cells and residual tissue (Figure 4), higher values being measured after 2 days of treatment. As expected, FSH also increased ovarian weight and induced formation of antra (data not shown).

\section{Effects of OLH on Ovarian Cell Proliferation}

Richards et al. (1976) have reported that ovaries of estradiol FSH-primed, hypophysectomized rats contain many large antral follicles rich in LH receptor which undergo luteinization in response to oLH $(60 \mu \mathrm{g})$. To determine the effects, if any, of oLH on ovarian cell proliferation in association with luteinization, a single injection $(60 \mu \mathrm{g})$ of oLH was administered to rats primed with estradiol (4 days) and FSH ( 2 days).

The effects of oLH on specific cell types differed. LH caused a marked decline in proliferative activity of the luteinizing granulosa cells within $24 \mathrm{hr}$, as observed by the decrease in the labeling index (3.7 fold) (Figure 1A) and in the incorporation ratio (3 fold) (Figure 1B). By $48 \mathrm{hr}$, no major changes in either the incorporation ratio or the labeling index 

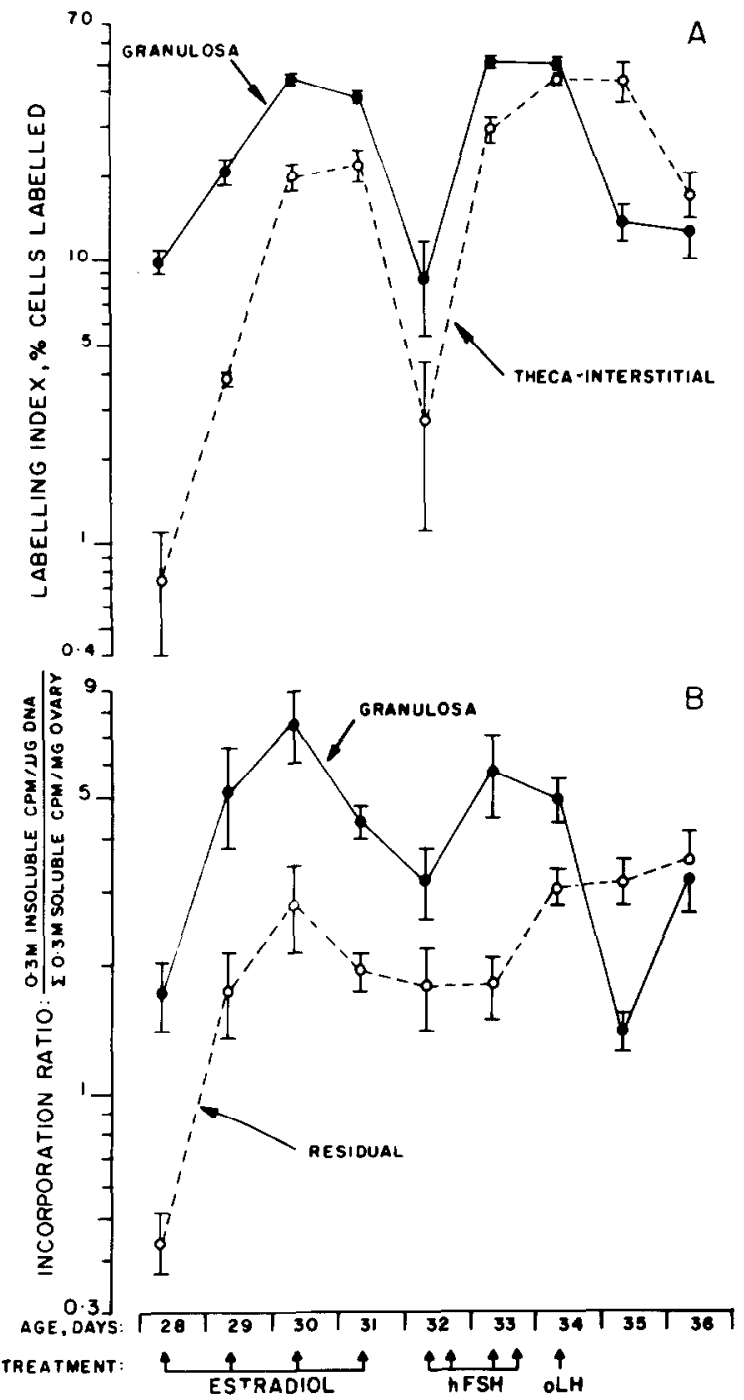

Figure 1A. Labeling Index

Animals at various stages of the model system received ${ }^{3} \mathrm{H}$ thymidine ( $15 \mu \mathrm{Ci} / \mathrm{g}$ body weight; spec. act. $45 \mathrm{Ci} / \mathrm{mmole}) 1 \mathrm{hr}$ prior to killing. The animals were killed with an overdose of ether, and the ovaries were processed as described in Experimental Procedures. The labeling index, determined from the autoradiographs, was calculated in the granulosa and the theca interstitial components individually as the percentage of cells that are labeled (for example, number of labeled granulosa cells $\times 100 \div$ total number of granulosa cells). The ordinate represents the percentage labeling index. The abscissa indicates the age of animals in days and the hormonal treatments administered. Each arrow represents a single subcutaneous injection. Doses administered were as described in the text. Animals were hypophysectomized on day 24 of age. Each point represents the mean \pm SEM of five observations. (-) granulosa cells; $\left(\mathrm{O}_{-}-\mathrm{O}^{-}\right)$theca interstitial cells.

Figure 1B. Incorporation Ratio

The ${ }^{3} \mathrm{H}$-thymidine incorporated into DNA was determined as described in Experimental Procedures. The label incorporated into DNA was expressed as follows: incorporation ratio $=0.3 \mathrm{M}$ insoluble cpm per $\mu \mathrm{g}$ DNA (granulosa or residual tissue)/0.3 M soluble cpm (granulosa + residual tissue) per mg ovary - that is, incorporation ratio represents uptake of label into DNA/concentration of available label. The ordinate represents incorporation were seen. Administration of saline in lieu of LH caused a less dramatic decrease in both the incorporation ratio and the labeling index (data not shown).

In contrast to its effects on luteinizing granulosa cells, LH did not significantly alter the FSH-stimulated increase in proliferative activity of the nongranulosa tissue at $24 \mathrm{hr}$, as reflected in both the labeling index and the incorporation ratio. By $48 \mathrm{hr}$ after the $\mathrm{LH}$ injection, a 2.6 fold drop in labeling index of theca interstitial tissue was seen, whereas the incorporation ratio did not differ from the $24 \mathrm{hr}$ value as shown in Figures $1 \mathrm{~A}$ and $1 \mathrm{~B}$. Unlike the effects of estradiol and FSH on granulosa cells, $\mathrm{LH}$ increased the concentration of label in the $0.3 \mathrm{M}$ percholoric acid-soluble fraction of luteinizing granulosa cells and residual tissue as seen in Figure 3.

Histological examination of the LH-stimulated ovaries revealed a large number of luteinizing follicles (containing granulosa and theca cells with increased cytoplasmic to nuclear ratios) with a progressive invasion, over time, of stromal elements into the developing corpora lutea. Furthermore, the majority of the reduced silver grains within the developing corpora lutea (at 24 and 48 hr) were associated with the invading stromal elements. As shown in Figures $2 \mathrm{H}$ and $2 \mathrm{l}$, few reduced silver grains could be seen on the luteinizing granulosa cells. With the resolution of the techniques used, it was difficult to ascertain whether any of these cells were luteinizing granulosa cells or whether all were associated with stromal elements.

LH caused an increase in ovarian weight (data not shown). This increase is reflected in an increase in the DNA content only in the residual tissue (2.2 fold) (Figure 4).

\section{Discussion}

This study examines and presents quantitative data on the differential effects of steroid (estradiol) and protein (FSH and LH) hormone on cellular proliferation of various cell types in the ovary. The results corroborate previous evidence that follicular growth and granulosa cell proliferation are enhanced by estrogens and $\mathrm{FSH}$, and that luteal cells do not undergo proliferation (Pencharz, 1940; Williams, 1940; Bradbury, 1961; Ryle, 1969; Pedersen and Peters, 1971; Goldenberg et al., 1972; Bartosik et al., 1974; Gospodarowicz and Gospodarowicz, 1975).

The specific activity of thymidine triphosphate (TTP) was not measured in this study. Instead, an

ratio, and the abscissa represents treatment groups as described for Figure 1A. Each point represents the mean $\pm \operatorname{SEM}(n=5)$. (0-_-_- granulosa cells; $\left(\mathrm{O}-\mathrm{-O}_{-}\right.$) residual tissue. 
attempt to correct for pool size was made by analyzing the incorporation of label into DNA (0.3 $M$ acid-insoluble label) in relation to the concentration of $0.3 \mathrm{M}$ acid-soluble label in the ovary. As shown in Figure 3, while estradiol and FSH did not alter the concentration of acid-soluble label, LH caused an increase. This $\mathrm{LH}$-induced increase in soluble labeled precursor cannot solely account for the $\mathrm{LH}$-induced alterations in incorporation ratios (Figure 1B) of either the granulosa (decrease) or residual tissues (increase). LH also altered the amount of label incorporated into DNA (data not shown) in both granulosa (decrease) and residual tissues (increase). Thus the changes in incorporation ratios are truly reflective of changes in proliferative activity. This conclusion is also supported by autoradiographic evidence that LH induces a decrease in the labeling index of luteinizing granulosa cells and an increase in that of the theca interstitial tissue. Thus for this study, the assumption that changes in the specific activity of TTP do not occur without a concomitant change in the rate of DNA synthesis appears to be valid.

Based on this assumption, it appears that the observed high incorporation ratios in response to the estradiol and FSH treatments are due to a shortening of the S phase and other phases of the cell cycle (increased labeling index and heavily labeled cells). In contrast, prolonged estradiol treatment (4 days) appears capable of lengthening both the $S$ phase and other phases of the cycle (only lightly labeled cells and decreased labeling index). These changes occurred in both granulosa cells and theca interstitial tissue. Thus although the phase of the cell cycle at which estradiol and FSH act is not known, it is apparent that, depending upon the duration of treatment, these hormones can concomitantly increase or decrease the length of specific cell cycle phases. Alterations in generation time due to alterations in $S$ phase, such as those discussed here, have been reported for other systems (Pedersen and Gelfant, 1970).

In this model system, the effectiveness of a given hormone in stimulating cell proliferation appears to depend on both the type of cell and its stage of development, and appears to be restricted over time. Similar findings have been reported for other model systems (Young, 1961; Stormshak et al., 1976). As shown in Figure 1, while estradiol and FSH were both capable of stimulating granulosa cell proliferation, continued administration of either hormone resulted in a decrease in the proliferative activity of granulosa cells. Furthermore, as shown in Figures 1, 2H and 21, LH-induced luteinization appears to be associated with a cessation of granulosa cell proliferation. This effect of LH appears to be highly stable since even $48 \mathrm{hr}$ after $\mathrm{LH}$ administration when serum concentrations of LH are low (Rao et al., 1977), there is no resumption of proliferative activity by the luteinized cells. This postulate is supported by the observations that cells of the corpora lutea of pregnancy (Pedersen and Peters, 1971) and of the cycle (A. Hirshfield, personal communication) do not incorporate ${ }^{3} \mathrm{H}$-thymidine, and that in response to $\mathrm{LH}$, "luteal" cells in culture cease to proliferate (Gospodarowicz and Gospodarowicz, 1975). These hormone-induced changes in proliferative activity can be correlated with hormone-induced changes in receptor content, responsiveness of the granulosa cell adenylate cyclase system and specific morphological growth stages observed in a similar experimental model (Richards et al., 1976; Richards, Rao and Ireland, 1977). Stimulation of proliferation by estradiol can also be correlated with estrogen-induced increase in ovarian responsiveness to gonadotropins (Louvet and Vaitukaitis, 1976). Thus as granulosa cells differentiate, they appear to require different hormonal stimuli for the regulation of DNA synthesis. Furthermore, in the absence of appropriate hormonal stimuli, the follicles become atretic. The requirement for appropriately timed hormonal stimuli to regulate proliferation may be one of the mechanisms determining whether cells of a given follicle continue to survive and differentiate, or ultimately undergo atresia.

Few attempts have been made to examine the effects of hormones on stimulation of proliferation in ovarian cell types other than granulosa cells (Hori et al., 1970; Eshkol and Lunenfeld, 1972; Goldenberg et al., 1972). Unlike the membrana granulosa, the nongranulosa ovarian compartment

Figure 2. Autoradiographic Localization of Administered ${ }^{5} \mathrm{H}$-Thymidine

Ovaries from various treatment groups were handled as described in Figure 1A. Photographs were taken with the reduced silver grains in focus; consequently details of tissue histology may not be clearly visible. All sections were photographed under identical conditions and are printed at a final magnification of $90 \mathrm{X}$.

(A) Age: day 28; hypophysectomized controls.

(B) Age: day 29; estradiol $(2.0 \mathrm{mg}$ per day) $\times 1$ day.

(C) Age: day 30 ; estradiol $(2.0 \mathrm{mg}$ per day) $\times 2$ days.

(D) Age: day 31 ; estradiol $(2.0 \mathrm{mg}$ per day) $\times 3$ days.

(E) Age: day 32; estradiol (2.0 $\mathrm{mg}$ per day) $\times 4$ days.

(F) Age: day 33; estradiol (2.0 mg per day) $\times 4$ days; hFSH (LER-1577), ( $1 \mu \mathrm{g} \times 2$ per day) $\times 1$ day.

(G) Age: day 34; estradiol (2.0 mg per day) $\times 4$ days; hFSH (LER-1577), ( $1 \mu \mathrm{g} \times 2$ per day) $\times 2$ days.

( $H$ and I) Age: days 35 and 36 ; estradiol (2.0 mg per day) $\times 4$ days; hFSH (LER-1577), $(1 \mu \mathrm{g} \times 2$ per day) $\times 2$ days; oLH (LER-1374A), (60 $\mu \mathrm{g}$ per injection) $\times 1$ at 24 and $48 \mathrm{hr}$, respectively. 

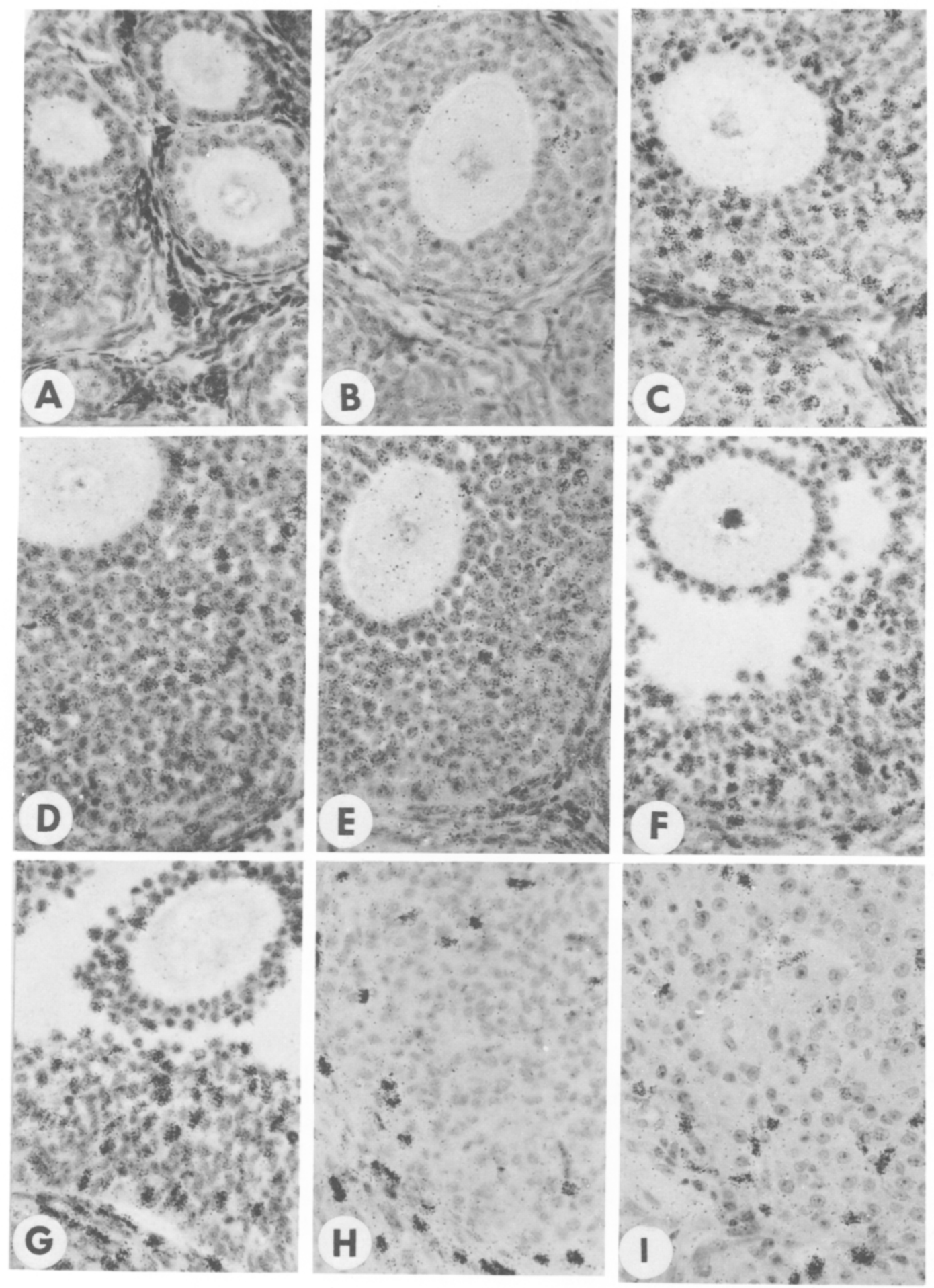


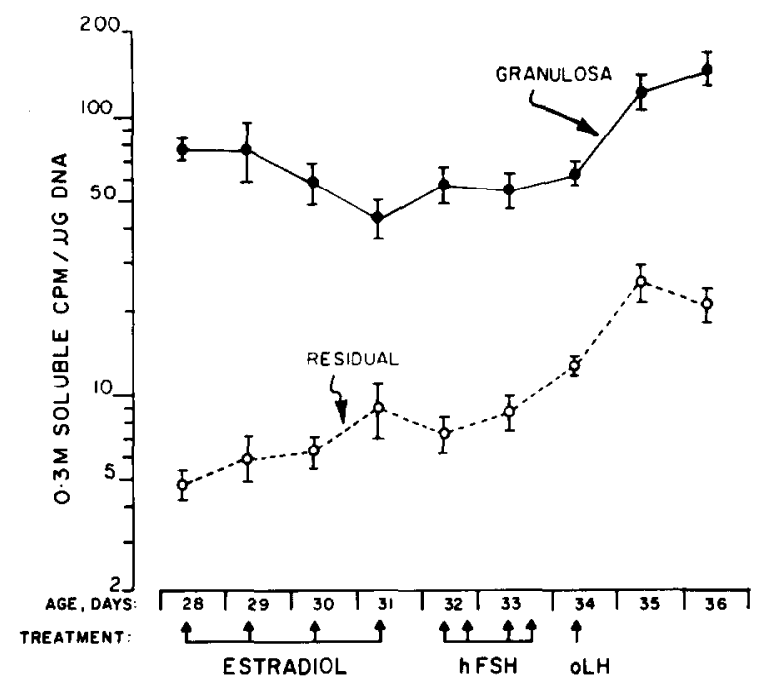

Figure 3. Acid-Soluble Fraction

The amount of label ( ${ }^{3} \mathrm{H}$-thymidine and its metabolites) present in the $0.3 \mathrm{M}$ perchloric acid-soluble fraction(s) was determined as described in Experimental Procedures. The ordinate represents the $\mathrm{cpm}$ present in the $0.3 \mathrm{M}$ acid-soluble fraction(s) per $\mu \mathrm{g}$ DNA. The abscissa is as described for Figure 1A. Each represents the mean \pm SEM $(n=5)$. ( $\longrightarrow)$ granulosa cells; $\left(0_{-}-0\right)$ residual tissue.

is comprised of several different cell types, including cells of the theca layer and interstitial tissue. Since the autoradiographic results indicated that hormonal stimulation of proliferation in the nongranulosa compartment was primarily restricted to cells of the theca layer (see Results), it would appear that the observed changes in the incorporation ratio of residual tissue were due to changes in proliferation of cells of the theca layer rather than those of the interstitium.

The discrepancy in the observations of the present study that estradiol can stimulate proliferation in the theca, and previously reported observations by Goldenberg et al. (1972) in which diethylstilbesterol did not appear to stimulate theca cell proliferation, could lie in the accuracy of determination of the number of labeled cells when they are present in low numbers. Thus although a 30 fold increase in labeling index was seen (Figure 1A), the actual number of labeled theca interstitial cells were very few (2/300 in control as opposed to 27 / 130 in maximally stimulated animals), and the stimulation observed could easily be missed. Furthermore, if there are only a few proliferating cells, there would then be only a slight increase in the total DNA content of the theca interstitial tissue and a discrepancy between relative changes in incorporation ratios and labeling indices. As shown in Figures 1,2 and 4, such changes were observed.

While it is probable that estradiol acts directly on the theca interstitial cells to stimulate proliferation (these cells appear to contain receptors for estra-

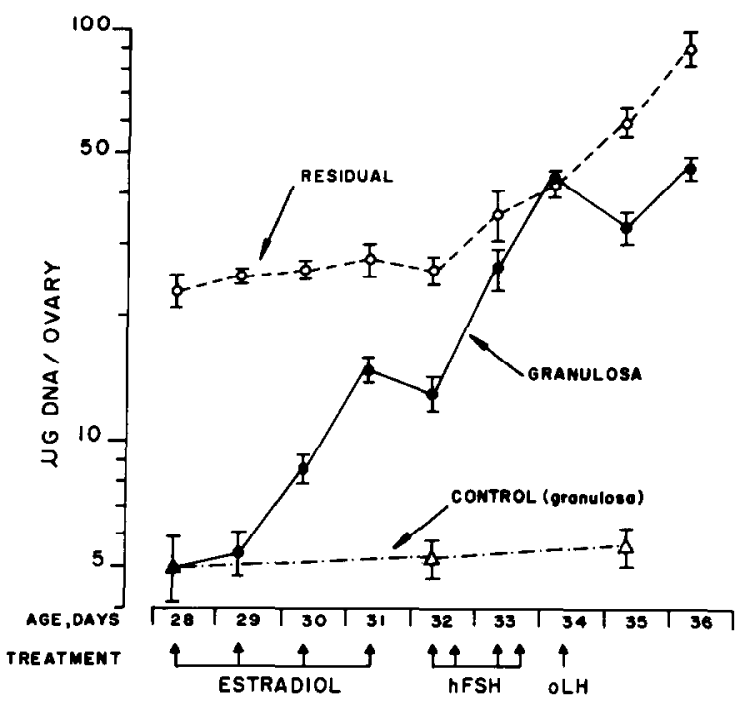

Figure 4. DNA Content

The DNA content of granulosa cells and residual tissues was measured by the Burton procedure as described in the text. The ordinate represents $\mu \mathrm{g}$ DNA per ovary in the two tissue types, and the abscissa is as described for Figure 1A. (-) granulosa cells of experimental groups; $(\Delta-\cdot-\cdot-\Delta)$ granulosa cells of hypophysectomized, untreated control animals; $\left(0_{-}-O^{-O}\right)$ residual tissue of experimental groups.

diol; Richards, 1975; Stumpf, 1969), the effect of FSH in stimulating theca cell proliferation suggests an indirect action since there is no evidence for the occurrence of FSH receptor in theca cells (Midgley, 1974). Since the FSH preparation is highly purified, it is improbable that $\mathrm{LH}$ contaminating the FSH preparation is responsible for theca cell proliferation. Although FSH is known to mediate some of its effects via estradiol, estradiol alone does not appear to be the intercellular mediator for this effect of FSH, since continued estradiol treatment did not cause extensive theca cell proliferation.

In contrast to the effects of LH on decreasing the proliferative activity of luteinizing granulosa cells, LH initially maintained the proliferative activity within the theca cells but only until $48 \mathrm{hr}$, when theca as well as granulosa cell luteinization is complete. LH also stimulated an increase in the number of heavily labeled cells which could be identified as stromal elements associated with the vascularization of the newly formed corpora lutea. The mechanisms of the LH-induced stimulation of stromal elements is unknown and most probably reflects an indirect action, since these cells have not been shown to contain LH receptors.

In summary, while estradiol and FSH act on follicles at different stages of development and differentiation to stimulate proliferation in both granulosa and theca cells, the capacity of either hormone to stimulate proliferation is limited. In contrast, ovulatory doses of LH cause a rapid 
cessation of proliferation in luteinizing granulosa cells while stimulating limited proliferation of cells within the theca. In the absence of the appropriate hormonal stimuli, the follicles undergo atresia. Thus specific sequential hormonal stimuli are required for continual follicular growth and development. In their presence, granulosa and theca cells proliferate and differentiate until, in response to a luteinizing dose of $\mathrm{LH}$, they cease to proliferate and enter a final stage of "irreversible" differentiation. The mechanisms by which steroid and protein hormones, acting via different intracellular mediators, regulate proliferation in the same cell type is an intriguing question that remains to be elucidated.

\section{Experimental Procedures}

\section{Materials}

Estradiol-17 $\beta$ was obtained from Sigma (St. Louis, Missouri) Human FSH (LER-1577, FSH activity per mg equivalent to 880 IU: First International Reference Preparation of Human Pituitary Gonadotropin for Bioassay) which had been treated with chymotrypsin to inactivate biologically active contaminating $\mathrm{LH}(<4 \mathrm{IU} \mathrm{LH}$ per $\mathrm{mg}$ by radioreceptor assay) and ovine LH [LER-1374A (39-49), LH activity $2.01 \times$ NIH-LH-S1 units per mg; FSH activity $<0.43 \times$ NIH-FSH-S1 units per $\mathrm{mg}$ ) were administered subcutaneously in $0.1 \%$ gelatin in $0.01 \mathrm{M}$ phosphate-buffered $0.14 \mathrm{M} \mathrm{NaCl}$ (pH 7.0) (gel-PBS). The protein hormones and the associated estimates of biological activity (obtained by ovarian ascorbic acid depletion and ovarian augmentation bioassays) were provided by Dr. Leo $E$. Reichert, Jr. ${ }^{3} \mathrm{H}$-thymidine, obtained from Nuclear Dynamics (California) (spec. act. 25-45 Ci/mmole), was administered intraperitoneally in PBS to all rats $1 \mathrm{hr}$ before killing. Paraplast for embedding tissues was obtained from Scientific Products. All other chemicals including those for Bray's scintillation fluid (Bray, 1960) were of spectral analytical grade.

\section{Animals}

Immature female hypophysectomized rats were purchased from Hormone Assay Laboratories (Chicago, Illinois) and maintained on pelleted rat food, fresh fruit and water ad libitum. Animals were hypophysectomized on day 24 of age. and hormone treatment, similar to that reported earlier (Richards, 1975), was commenced on day 28 of age. Briefly, hypophysectomized rats were injected subcutaneously with vehicle or estradiol $(2.0 \mathrm{mg} / 0.2 \mathrm{ml}$ propylene glycol per day) for 1-4 days. To study the effects of protein hormones, rats primed with estradiol were treated with hFSH ( $1 \mu \mathrm{g} \times 2$ per day) for 1 or 2 days or with hFSH for 2 days followed by a single injection of oLH $(60 \mu \mathrm{g})$.

\section{Procedures}

Proliferation has been assessed on the basis of autoradiographic localization of ${ }^{3} \mathrm{H}$-thymidine in nuclei of granulosa cells and nongranulosa ovarian cells, and biochemical assessment of DNA content and incorporation of ${ }^{3} \mathrm{H}$-thymidine into the DNA of these two cell types.

Autoradlographic Analyses

Rats from each stage of hormone treatment were injected intraperitoneally with ${ }^{3} \mathrm{H}$-thymidine $(15 \mu \mathrm{Ci} / \mathrm{g}$ body weight) in $0.9 \mathrm{ml}$ distilled water. $1 \mathrm{hr}$ later, animals were killed with an overdose of ether. The ovaries and short segments of the small intestine (used as control tissue) were removed and fixed in Bouin's fluid for 24 $\mathrm{hr}$ at room temperature. The tissues were dehydrated and embedded in paraplast by routine histological procedures (Preece 1972). Complete serial sections of $5 \mu \mathrm{m}$ thickness of each ovary were prepared. The sections were then heavily stained with Harris' alum hematoxylin (15 min) and "Navy Manual Alcoholic Eosin" (30 $\mathrm{min}$ ) (Preece, 1972). This was done to ensure reasonable staining, since autoradiographic development procedures are known to wash out the majority of the stain. Autoradiograms were processed according to the method of Rajaniemi and Midgley (1975). Briefly, slides were coated with nuclear emulsion (Kodak NTB-2), exposed for 12 days at $-20^{\circ} \mathrm{C}$ and developed for $6 \mathrm{~min}$ at $19^{\circ} \mathrm{C}$ in D170. The sections were examined for specific concentration of reduced silver grains over nuclei, and representative areas were photographed. In each photomicrograph, the ratio of labeled to unlabeled cells (labeling index) was determined independently in the granulosa cells and the theca interstitial tissue as indices of the number of cells actively undergoing DNA synthesis in the two tissue types. A cell with 7 or more reduced silver grains was considered as labeled; cells with 7-14 grains were classed as lightly labeled, and those with more than 14 grains as heavily labeled. In the early stages of the model system (controls, estradiol treatments for 1 and 2 days), the theca layers were not clearly distinguishable from the interstitial tissue. Accordingly, for the sake of uniformity, the tissue types have been arbitrarily classified as granulosa cells and as theca interstitial tissue (comprising theca cells, stromal elements and other interstitial cells). Blochemical Anatysis

To determine quantitatively the amount of ${ }^{3} \mathrm{H}$-thymidine incorporated into DNA, a modification of the method described by Tachi. Tachi and Lindner (1972) was used. Rats from each stage of treatment were injected intraperitoneally with $200 \mu \mathrm{Ci}$ of ${ }^{3} \mathrm{H}$ thymidine in $0.4 \mathrm{ml}$ of distilled water. $1 \mathrm{hr}$ later, animals were decapitated, the trunk blood was collected and centrifuged at 800 $\times \mathrm{g}$ for $20 \mathrm{~min}$, and $10 \mu \mathrm{l}$ of the serum were counted. The ovaries were removed, trimmed of extraovarian tissues, weighed and placed in cold PBS on ice. The granulosa cells were isolated in 1 $\mathrm{ml}$ of $0.25 \mathrm{M}$ sucrose, $0.01 \mathrm{M}$ Tris EDTA by applying gentle pressure with a blunt spatula according to the method of Zeleznik, Midgley and Reichert (1974). The remainder of the ovary, designated as the residual ovarian tissue (containing theca interstitial tissue plus any unexpressed granulosa cells), was dispersed in 1 $\mathrm{ml}$ of PBS. Each tissue was homogenized in all-glass Pyrex tissue grinders (6-8 strokes), and concentrated percholoric acid was added to the homogenate to a final concentration of $0.3 \mathrm{M}$. The homogenates were centrifuged at $1500 \times \mathrm{g}$ for $10 \mathrm{~min}$, and the supernatant (S1) was saved. The pellet was washed with $1 \mathrm{ml}$ of $0.3 \mathrm{M}$ percholoric acid and recentrifuged at $1500 \times \mathrm{g}$ for $10 \mathrm{~min}$. The supernatant of this washed fraction was pooled with $S 1$ and represented the $0.3 \mathrm{M}$ acid-soluble fraction (S). Only traces of radioactivity could be detected in the supernatant on repeated washings. The washed pellet was hydrolyzed in $1 \mathrm{ml}$ of $0.6 \mathrm{M}$ perchloric acid at $90^{\circ} \mathrm{C}$ for $20 \mathrm{~min}$ in a shaking incubator and cooled. Insoluble material (Im) was removed from the hydrolysate, and the supernatant was designated as the $0.3 \mathrm{M}$ acid-insoluble fraction (1). Aliquots of $300 \mu$ l of the $0.3 \mathrm{M}$ soluble (S) and insoluble (I) fractions were assayed for DNA content using the procedure of Burton (1956). The insoluble material $(\mathrm{Im})$ remaining after hydrolysis with $0.6 \mathrm{M}$ perchloric acid was further hydrolyzed, and the DNA content was measured. In all cases, the DNA content of the $\mathrm{Im}$ and $\mathrm{S}$ fractions was below the limits of detection of the assay. Further aliquots of all fractions (S, I and $I \mathrm{~m}$ ) were neutralized with $2.0 \mathrm{M} \mathrm{KOH}$, and the insoluble potassium perchlorate was removed by centrifugation. $300 \mu l$ of the resulting supernatants were counted in $10 \mathrm{ml}$ of Bray's scintillation fluid by scintillation spectrometry. Suitable corrections were made for quenching, and the results were expressed for each tissue as follows: incorporation ratio $=$ uptake of label into DNA/concentration of available label $=0.3 \mathrm{M}$ insoluble (I) $\mathrm{cpm}$ per $\mu \mathrm{g}$ DNA/ $0.3 \mathrm{M}$ soluble (S) $\mathrm{cpm}$ per $\mathrm{mg}$ ovary, where label represents ${ }^{3} \mathrm{H}-$ thymidine (or its metabolites). Uptake of label into DNA was measured by determining the $\mathrm{cpm}$ in the $0.3 \mathrm{M}$ acid-insoluble fraction (I) present per $\mu g$ DNA. An estimation of the concentration of available ${ }^{3} \mathrm{H}$-thymidine was determined as the sum of the $\mathrm{cpm}$ present in the $0.3 \mathrm{M}$ acid-soluble fraction (S) of granulosa 
cells and residual tissues per mg ovary. In all cases, only traces of radioactivity remained in the Im fraction.

Determination of the Efficiency of the Expression of Granulosa Cells

As a means of estimating the extent to which nonexpressed granulosa cells contaminated the residual tissue, the content of FSH receptor was assessed in granulosa cells, residual tissue and the whole ovary. The content of FSH receptor was determined by radioreceptor measurements using ${ }^{25} \mathrm{~h}-\mathrm{hFSH}$ as the labeled ligand by methods described (Richards et al., 1976). We have previously shown by topical autoradiography that highly purified preparations of ${ }^{225}$-hFSH (obtained when necessary by elution from polyacrylamide gels following electrophoresis) bind exclusively to granulosa cells and not to luteal cells, theca cells or interstitial cells (Midgley, 1974). Furthermore, we have not been able to demonstrate specific binding of purified ${ }^{125} \mathrm{I}-\mathrm{hFSH}$ to any fractions from Isolated rat corpora lutea when studled by radioreceptor assay (unpublished observations).

\section{Acknowledgments}

The authors would like to thank the members of the Reproductive Endocrinology Program for their support and cooperation, and Dr. L.E. Reichert, Jr. for the supply of hormones. The study was supported in part by a Program Project Grant in Reproductive Endocrinology, a research grant and a Ford Foundation Training Grant.

The costs of publication of this article were defrayed in part by the payment of page charges. This article must therefore be hereby marked "advertisement" in accordance with 18 U.S.C. Section 1734 solely to indicate this fact.

Received August 8, 1977; revised February 28, 1978

\section{Reterences}

Bartosik, D., Szarowski, D.H. and Stone, M.L. (1974). Proc. Soc. Exp. Biol. Med. 145, 85.

Bradbury, J.T. (1961) Endocrinology 68, 115.

Bray, G.A. (1960). Anal. Biochem. 1, 279.

Burton, K. (1956). Biochem. J. 62, 315.

Eshkol, A. and Lunenfeld, B. (1972). In Gonadotropins, B.B. Saxena, C.G. Beling and H.M. Gandy, eds. (New York: John Wiley and Son), p. 335.

Goldenberg, R.L., Vaitukaitis, J.L. and Ross, G.T. (1972). Endocrinology 90, 1492.

Goldenberg, R.L., Reiter, E.O, and Ross, G.T. (1973). Fertil. Steril. 24, 121

Gospodarowicz, D. and Gospodarowicz, F. (1975). Endocrinology $96,458$.

Hori, T., Ide, M., Kato, G. and Miyake, T. (1970). Endocrinol. Jap. 17, 489.

Louvet, J.P. and Vaitukaitls, J.L. (1976). Endocrinology 99, 758.

Midgley, A.R., Jr. (1974). Adv. Exp. Med. Biol. 37, 365.

Pedersen, T. and Gelfant, S. (1970). Exp. Cell Res. 59, 32.

Pedersen, T. and Peters, H. (1971). Fertil. Steril. 21, 42

Pencharz, R.J. (1940). Science 91, 554.

Preece, A. (1972). A Manual for Histological Technicians (Boston: Little, Brown)

Rajaniemi, H.J. and Midgley, A.R., Jr. (1975). In Methods in Enzymology, 37B, B.W. O'Malley and J.G. Hardman, eds. (New York: Academic Press), p. 145.

Rao, M.C., Richards, J.S., Midgley, A.R., Jr. and Reichert, L.E., Jr. (1977), Endocrinology 101, 512.

Richards, J.S. (1975). Endocrinology 97, 1174.

Richards, J.S. and Midgley, A.R., Jr. (1976). Biol. Reprod. 14, 82. Richards, J.S., Rao, M.C. and Ireland, J.J. (1977). In Control of
Ovulation, University of Nottingham Easter Symposium, in press. Richards, J.S., Ireland, J.J., Rao, M.C., Bernath, G.A., Midgley, A.R., Jr. and Reichert, L.E., Jr. (1976). Endocrinology 99, 1562. Ryle, M.J. (1969). J. Reprod. Fertil. 19, 87.

Stormshak, F., Leake, R., Wertz, N. and Gorski, J. (1976). Endocrinology 99, 1501.

Stumpf, W.E. (1969). Endocrinology 85, 31.

Tachi, C., Tachi, S. and Lindner, H.R. (1972). J. Reprod. Fertil. $31,59$.

Williams, P.C. (1940). Nature 145, 388.

Young, W.C., (1961). In Sex and Internal Secretions, W.C. Young, ed. (Baltimore: Williams and Wilkins), p. 449.

Zeleznik, A.J., Midgley, A.R., Jr. and Reichert, L.E., Jr. (1974). Endocrinology 95, 818. 